\title{
EVALUASI TERHADAP ASPEK KEBERSIHAN DAN KESUCIAN DALAM PERANCANGAN ARSITEKTUR MASJID
}

Moh. Arsyad Bahar
Jabatan Seni Bina, Fakulti Kejuruteraan dan Alam Bina, Universiti Kebangsaan Malaysia, Bangi, Selangor Darul Ehsan, Malaysia

e-mail: ab_kyura@yahoo.co.id

\begin{abstract}
Cleanliness and purity are two of primary things in Islam. Moslems are supposed to maintain their cleanliness and purity in every aspect of their lives. In mosques, cleanliness of place is one of the most important aspects to be concerned because it is closely related to worship activities. However, mosques architecture these days are more concern about the aesthetical aspect rather than the cleanliness aspect. In this paper, an evaluation for the islamic cleanliness (thaharah) aspect has been explained for some great mosques, i.e. Jami' Mosque Malang, an-Nur Mosque Pare Kediri, and A.R. Fachruddin Mosque Muhammadiyah University of Malang. In these great mosques, the cleanliness and the purity problems often appear because of the failure in design, such as the position and the design of toilet, the thaharah system, the visitors' circulation, the building maintenance, etc. Because of these problems, a design guideline which has a priority in the aspect of cleanliness that can be applied in other mosques' architectural design is also described in this paper.
\end{abstract}

Keywords: thaharah, mosque architecture, cleanliness

\begin{abstract}
Abstrak
Aspek kebersihan dan kesucian dalam Islam menjadi hal yang diutamakan. Umat Islam dianjurkan untuk selalu menjaga kebersihan dan kesucian dalam segala hal. Di masjid, kebersihan tempat merupakan salah satu aspek yang sangat penting untuk diperhatikan karena berhubungan langsung dengan hal ibadah. Desain arsitektur masjid sekarang ini lebih mengedepankan unsur estetik yang menyebabkan aspek kebersihan dan kesucian sering terabaikan. Evaluasi terhadap aspek kebersihan dan kesucian dilakukan pada beberapa masjid besar, seperti Masjid Jami' Kota Malang, Masjid An-Nur Pare Kabupaten Kediri dan Masjid A.R. Fachruddin Universitas Muhammadiyah Malang. Pada masjid-masjid tersebut, permasalahan kebersihan dan kesucian yang sering muncul disebabkan karena desain masjid yang kurang tepat, seperti tata letak, desain tempat wudhu dan toilet, sistem thaharah, pemeliharaan bangunan dan lain sebagainya. Dengan adanya permasalahanpermasalahan tersebut, maka diperlukan sebuah solusi desain yang universal sehingga nantinya dapat diterapkan pada semua desain arsitektur masjid yang lebih mengutamakan aspek kebersihan dan kesucian.
\end{abstract}

Kata kunci: kebersihan, kesucian, arsitektur masjid

\section{Pendahuluan}

Menurut bahasa (etimologi), masjid berarti tempat beribadah. Kata masjid sendiri berakar dari bahasa Arab, akar kata dari masjid adalah sajada dimana sajada berarti sujud atau tunduk. Kata masgid (m-s-g-d) ditemukan dalam sebuah inskripsi dari abad ke-5 sebelum masehi yang berarti "tiang suci" atau "tempat sembahan". Berdasarkan akar kata tersebut, hakikat dari masjid adalah tempat melakukan segala aktivitas yang berkaitan dengan kepatuhan kepada Allah semata. Oleh karena itu, masjid dapat diartikan lebih jauh, bukan hanya tempat shalat dan bersuci (berwudhu), namun juga sebagai tempat melaksanakan segala aktivitas kaum muslimin berkaitan dengan kepatuhan kepada Allah swt. ${ }^{1}$

Selanjutnya, terdapat pula pengertian masjid menurut istilah (terminologi), yaitu tempat membina umat, yang meliputi penyambung ukhuwah, wadah membicarakan masalah umat, serta pembinaan dan pengembangan masyarakat, karena masjid selain berfungsi memenuhi keperluan ibadah Islam, fungsi dan perannya ditentukan juga oleh lingkungan, tempat dan jamaah di mana masjid didirikan. ${ }^{2}$

Terdapat tiga fungsi dan peran masjid. Pertama, sebagai tempat ibadah mahdhah. Kedua, memanfaatkan masjid sebagai pusat kegiatan muamalah atau ibadah ghoiru mahdhah, yaitu untuk pengembangan masyarakat melalui berbagai sarana dan prasarana yang dimiliki masjid. Ketiga, masjid sebagai pusat pembinaan persatuan umat.

Dengan kompleksnya fungsi dan aktivitas yang diwadahinya, maka perancangan arsitektur masjid harus benar-benar memperhatikan aspek-aspek hablumminallah, hablumminannas dan hablumminal'alam di dalam rancangannya. Dari ketiga aspek ini, terdapat berbagai prinsip yang terdapat di dalam sebuah masjid, misalnya prinsip kemanfaatan, 
keterbukaan, keindahan, kebersihan, keselarasan dengan alam, dan sebagainya. Prinsip kebersihan dan kesucian masjid yang akan dibahas di dalam tulisan ini merupakan salah satu aspek yang sangat penting di dalam sebuah masjid sebagai tempat ibadah. Allah swt berfirman di dalam al-Qur'an surat at-Taubah ayat 108 sebagai berikut:

"Sesungguhnya mesjid yang didirikan atas dasar takwa (mesjid Quba), sejak hari pertama adalah lebih patut kamu bersembahyang di dalamnya. Di dalamnya ada orang-orang yang ingin membersihkan diri. Dan Allah menyukai orang-orang yang bersih." 3

Selain itu, terdapat juga cukup banyak hadits yang menjelaskan mengenai kebersihan dan kesucian, salah satunya adalah hadits yang diriwayatkan oleh Imam Tirmidzi sebagai berikut:

"sesungguhnya Allah baik dan menyukai kebaikan, bersih dan menyukai kebersihan, murah hati dan senang kepada kemurahan hati, dermawan dan senang kepada kedermawanan. Karena itu bersihkanlah halaman rumahmu dan janganlah meniru-meniru orang yahudi." ${ }^{4}$

Dalam perancangan arsitektur masjid, kebersihan dan kesucian menjadi pertimbangan utama, karena kebersihan dan kesucian bagi seorang muslim memiliki dasar yang sangat kuat di dalam ajaran Islam. Kebersihan dan kesucian menjadi salah satu prasyarat sebelum melaksanakan ibadah sholat. Oleh karena itu, perancangan arsitektur masjid akan sangat menentukan tingkat kebersihan dan kesucian masjid yang bersangkutan.

Begitu pentingnya kebersihan menurut Islam, sehingga orang yang membersihkan diri atau mengusahakan kebersihan akan dicintai oleh Allah swt, sebagaimana firman-Nya di dalam surat alBaqarah ayat 222, "Sesungguhnya Allah menyukai orang-orang yang bertaubat dan orang-orang yang menyucikan/membersihkan diri". ${ }^{5}$

Secara bahasa, bersih adalah upaya manusia untuk memelihara diri dan lingkungannya dari segala yang kotor, sedangkan suci diartikan sebagai bersih, tidak berdosa. ${ }^{6}$ Sementara itu, di dalam kitab-kitab fiqih (ajaran hukum Islam), masalah yang berkaitan dengan kebersihan disebut "thaharah". AthThaharah secara etimologi berarti "kebersihan". Kebersihan menurut syariat mencakup kebersihan badan, busana, dan tempat. Makna "thaharah" mencakup aspek bersih lahir dan bersih bathin. Bersih lahir artinya terhindar (terlepas) dari segala kotoran, hadas, dan najis. Sementara itu, bersih bathin artinya terhindar dari sikap dan sifat tercela. ${ }^{7}$

Imam al-Ghazali mengemukakan di dalam kitab Ihya Ulumuddin (terjemahan), bahwa thaharah atau bersuci mempunyai empat tingkatan. Pertama, membersihkan anggota-anggota lahiriah dari hadas, najis-najis atau kotoran-kotoran serta benda-benda kelebihan yang tidak diperlukan. Kedua, membersihkan hati dan sifat tercela. Ketiga, membersihkan rahasia bathiniah dari sesuatu yang selain daripada
Allah, dan ini adalah thaharah-nya para nabi dan shiddiqin.

Di dalam Islam, terdapat beberapa aspek kebersihan, sebagai berikut:

1. Kebersihan rohani. Ajaran kebersihan mendasar adalah menyangkut kebersihan rohani, yaitu menjaga jiwa dan hati dari syirik dan maksiat atau perbuatan-perbuatan dosa yang menjadikan kotornya jiwa.

2. Kebersihan badan. Kebersihan badan dan jasmani merupakan hal yang tidak terpisahkan dengan kebersihan rohani, kebersihan badan yaitu menjaga diri dari hadats dan najis.

3. Kebersihan tempat. Ajaran kebersihan juga menyangkut kebersihan tempat kita melaksanakan ibadah atau sarana peribadatan. Mesjid sebagai tempat suci, di mana kaum muslimin melakukan ibadah harus dipelihara kesucian dan kebersihannya karena ibadah shalat tidak sah hukumnya jika dikerjakan di tempat yang tidak bersih atau kotor.

4. Kebersihan pakaian. Kebersihan pakaian dipandang penting dalam agama, mengingat pakaian melekat pada badan yang berfungsi menutup aurat, melindungi badan dari kotoran dan penyakit, serta memperindah badan, maka ajaran Islam menyatukan antara kebersihan badan dan kebersihan pakaian.

5. Kebersihan makanan. Ajaran Islam tentang kebersihan makanan menyatukan aspek kebersihan dari segi kesehatan dan kebersihan dalam arti makanan yang halal. Makanan yang halal adalah makan yang dibolehkan oleh agama (tidak diharamkan), sedangkan makanan yang baik adalah makanan yang memenuhi syaratsyarat kesehatan, termasuk makanan yang bersih, bergizi dan berprotein.

6. Kebersihan lingkungan. Ajaran Islam memandang penting kebersihan lingkungan hidup, menghindarkan pencemaran dari limbah dan sampah.

7. Kebersihan dalam rumah tangga. Ajaran Islam tentang kebersihan juga menyangkut keberihan rumah tangga, baik mengenai tempat tinggal, maupun soal hubungan antara anggota keluarga khususnya suami - istri.

8. Kebersihan harta. Ajaran Islam tentang kebersihan juga meliputi tentang kebersihan harta, karena di dalam harta terdapat hak Allah dan harta orang lain. Cara membersihkan harta ialah dengan membayar zakat harta, zakat fitrah, infaq dan sedekah.

Islam menghendaki dari umatnya kebersihan yang menyeluruh. Dengan kebersihan yang menyeluruh itu, diharapkan akan terwujud kehidupan manusia, individu, dan masyarakat yang selamat, sehat, bahagia dan sejahtera lahir dan bathin. ${ }^{8}$

Terkait dengan aspek kebersihan dan kesucian dalam perancangan arsitektur masjid, terdapat 
beberapa hal yang perlu diperhatikan, yaitu keadaan lingkungan masjid, aliran sirkulasi pengguna, perbedaan ketinggian lantai, tempat wudhu, toilet, aliran cahaya, air, dan udara, ornamen dan material, penataan lansekap, utilitas bangunan dan kawasan, tempat sampah, dan lain sebagainya.

\section{Analisis Kondisi Eksisting Masjid} Masjid Jami' Kota Malang

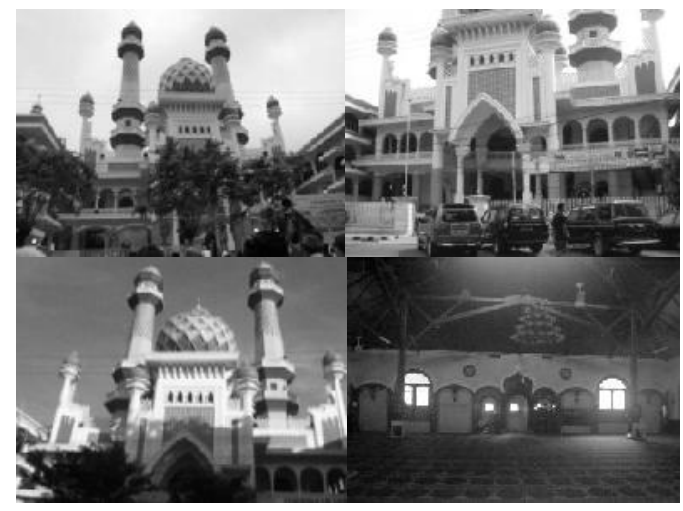

Gambar 1. Masjid Jami' Kota Malang (Sumber: Hasil dokumentasi, 2010)

Masjid ini berlokasi di sebelah barat Alun-Alun Kota Malang, berdiri sejak jaman kolonial Belanda dan telah mengalami beberapa kali renovasi. Namun demikian, bagian induk bangunan tetap dipertahankan bentukan aslinya. Perubahan terdapat pada bagian serambi depan, muka depan, menara, tempat wudhu, dan kamar mandi masjid. Masjid ini menjadi masjid Kota Malang dan letaknya yang tepat di depan alun-alun kota menjadikan masjid ini banyak dikunjungi dan ramai.

Aspek kebersihan dan kesucian pada masjid ini memiliki kelebihan dengan perancangan arsitektur masjid sebagai berikut:

- Adanya perbedaan ketinggian permukaan lantai. Untuk teras masjid dibuat cukup luas, lapang tanpa pagar dan suci.

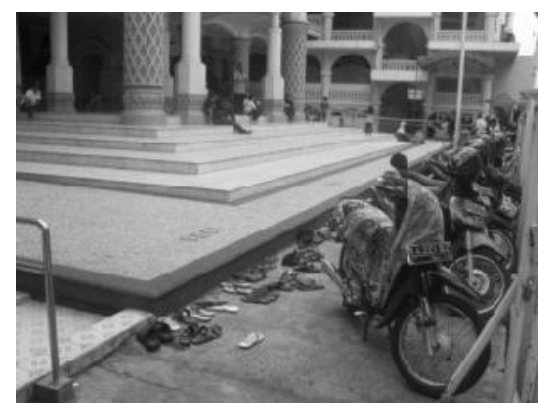

Gambar 2. Halaman depan Masjid Jami' Kota Malang (Sumber: Hasil dokumentasi, 2010)

- Tempat wudhu laki-laki berada di sebelah utara masjid, masuk ke dalam lantai basement. Terdiri dari tangga turun masuk kemudian terdapat dua kolam berurutan untuk pencuci kaki yang cukup lebar sedalam mata kaki.

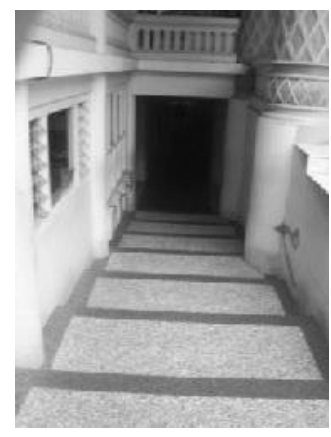

Gambar 3. Tempat wudhu dan toilet laki-laki (Sumber: Hasil dokumentasi, 2010)

- Kran air wudhu di desain dengan berjajar di dinding setinggi perut dan pada bagian bawahnya terdapat pijakan kecil untuk tempat kaki pada saat kaki dibasuh.

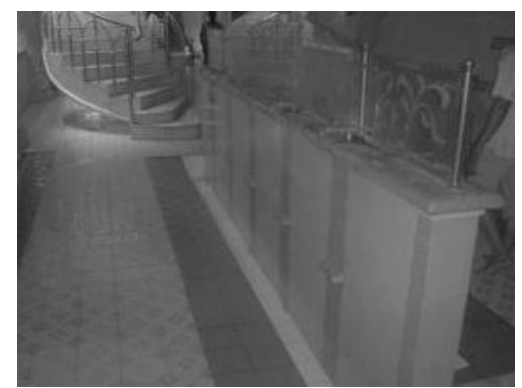

Gambar 4. Tempat wudhu pria

(Sumber: Hasil dokumentasi, 2010)

- Terdapat tangga naik ke lantai serambi di ujung tempat wudhu sehingga setelah wudhu tidak lagi harus kembali ke depan melewati kolam pencuci kaki.

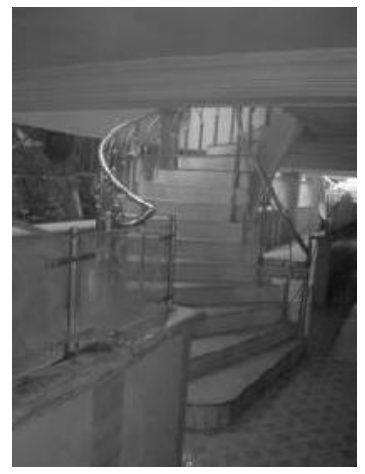

Gambar 5. Tangga tempat wudhu untuk naik ke lantai 1 (Sumber: Hasil dokumentasi, 2010)

- Sementara itu, sirkulasi udara dan cahaya cukup memadai dan diperoleh dari jendela-jendela dan pintu yang berukuran cukup besar di sisi kanan dan kiri masjid. 


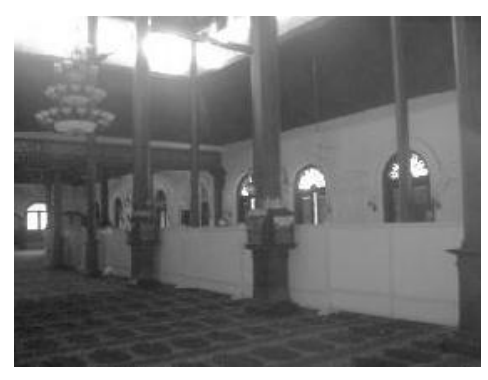

Gambar 6. Pintu dan jendela masjid (Sumber: Hasil dokumentasi, 2010)

- Pada sisi luar, fasad masjid terdapat ornamenornamen bergaya timur tengah yang cukup detail dan terdapat pada dinding yang tinggi sehingga perawatannya sedikit susah, menjadikan ornamen kurang terawat kebersihannya.

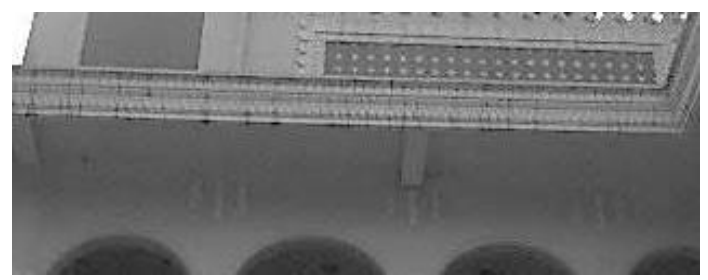

Gambar 7. Fasad masjid yang mulai kurang terawat (Sumber: Hasil dokumentasi, 2010)

Selanjutnya, kekurangan yang terdapat pada masjid ini terkait kebersihan dan kesucian sebagai berikut:

- Perbedaan ketinggian permukaan lantai teras masjid terlalu rendah dengan permukaan jalan raya dan pagar terbuat dari pagar jeruji besi, menjadikan teras cepat kotor terkena debu kendaraan dan kotoran lainnya.

- Kurangnya ruang lantai kotor/halaman untuk alas kaki, sendal maupun sepatu. Hanya terdapat sekitar 1,5 m jarak antara teras masjid dengan pagar.

- Bagi orang yang kakinya sudah bersih dan suci, jika ingin mengambil wudhu maka harus melewati kolam pencuci kaki.

- Terdapat dua kolam pencuci kaki yang sama dan cukup lebar menjadikan akses ke tempat wudhu menjadi sulit.

- Ornamen masjid yang berada pada dindingdinding yang tinggi menjadi tempat kotoran yang sulit untuk dibersihkan.

\section{Masjid An-Nur Pare Kediri}

Masjid An-Nur merupakan Masjid Agung Pare kabupaten Kediri yang dibangun pada pertengahan tahun 2000. Desain arsitektur masjid ini sesuai dengan namanya, yaitu "an-nuur" yang berarti cahaya. Didesain dengan konsep cahaya, ditonjolkan dengan penggunaan atap prisma skylight biru dimana pada saat siang hari cahaya matahari dapat direfleksikan masuk ke dalam ruangan dan pada malam hari prisma tersebut mengeluarkan cahaya dari lampu yang ada di dalamnya. Prisma tersebut disusun sengan struktur "space frame" atau rangka ruang dengan sistem penyambungan "mero". Selain pada atap tersebut, terdapat pula prisma-prisma serupa pada tiang-tiang yang ada di halaman masjid.

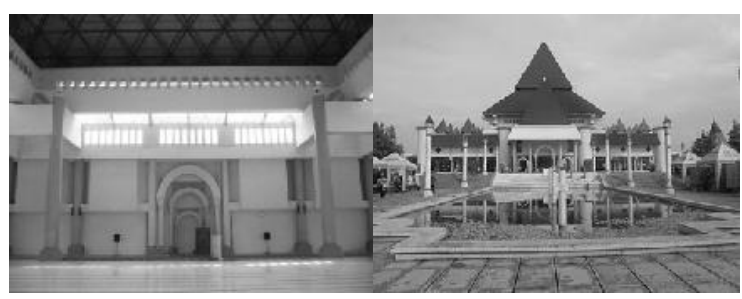

Gambar 8. Masjid An-Nur Pare Kabupaten Kediri (Sumber: Hasil dokumentasi, 2010)

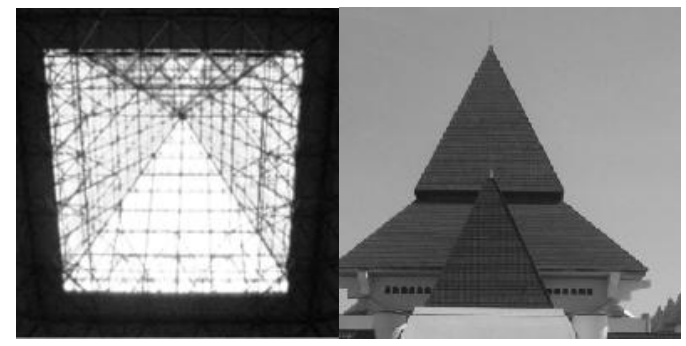

Gambar 9. Atap utama masjid

(Sumber: Hasil dokumentasi, 2010)

Terkait dengan aspek kebersihan dan kesucian dalam perancangan arsitektur masjid, masjid ini memiliki keunggulan sebagai berikut:

- Letak masjid dan jalan raya utama terpisah dengan taman masjid sehingga debu dan kotoran jalanan tidak masuk pada masjid.

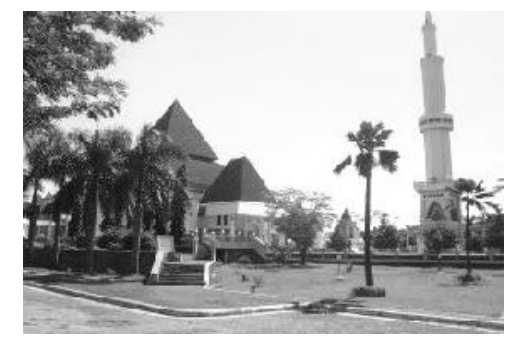

Gambar 10. Masjid dan lingkungan sekitar (Sumber: Hasil dokumentasi, 2010)

- Memiliki perbedaan level ketinggian permukaan lantai untuk jalan, halaman masjid dan bangunan sendiri.

- Terdapat penzoningan ruang penggunaan lahan, yaitu lahan untuk taman, halaman, sirkulasi, dan bangunan sehingga perawatan kebersihannya menjadi lebih mudah.

- Dinding bangunan masjid menggunakan material kaca dan ventilasi yang cukup, menjadikan bangunan mendapatkan sirkulasi cahaya dan 
udara dengan baik sehingga kondisi ruangan menjadi tidak lembab dan bersih.

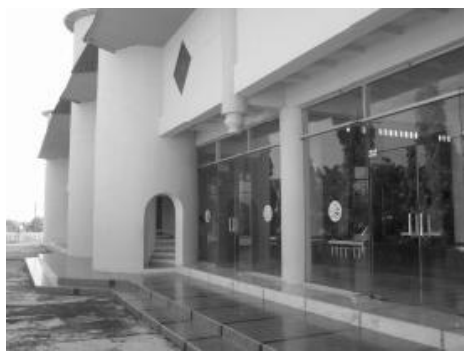

Gambar 11. Material kaca pada dinding (Sumber: Hasil dokumentasi, 2010)

- Pemisahan tempat wudhu dengan kamar mandi. Tempat wudhu berada di atas sejajar dengan lantai utama bangunan, sedangkan untuk kamar mandi berada di bawah tempat wudhu sejajar dengan permukaan tanah. Desain ini secara langsung telah memisahkan jenis thaharah-nya, sehingga kotorannya tidak bercampur mengenai tempat satu dan lainnya.

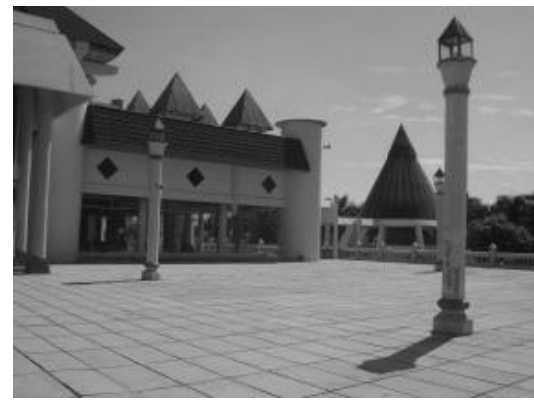

Gambar 12. Tempat wudhu dan kamar mandi (Sumber: Hasil dokumentasi, 2010)

- Pada tempat wudhu disediakan tempat duduk untuk memudahkan wudhu sehingga tangan tidak perlu memegang dinding kran yang biasanya cepat kotor dan berlumut.

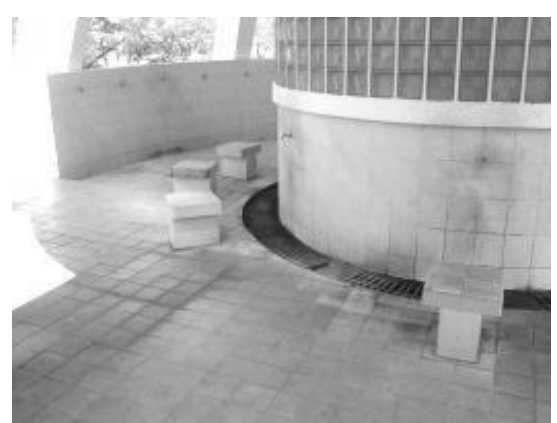

Gambar 13. Tempat wudhu dengan tempat duduk (Sumber: Hasil dokumentasi, 2010)

- Ornamen interior maupun eksterior pada dinding masjid tampaknya didesain sangat sederhana sehingga untuk perawatan kebersihannya juga akan lebih mudah.
Selain keunggulan-keunggulan tersebut, terdapat juga kekurangan desain arsitektur masjid terkait dengan kebersihan dan kesucian, yaitu:

- Terdapat halaman yang cukup luas melebihi luas lahan bangunan masjid. Halaman ini tidak beratap, hanya terdapat tiang-tiang. Halaman ini sangat panas di waktu siang hari, sedangkan di malam hari hempasan angin cukup kencang dan dingin. Kondisi ini menjadikan halaman ini kurang terawat kebersihannya. Terlebih lagi ditambah desain lantai yang bergaris-garis berlubang, sebenarnya desain ini digunakan untuk drainase halaman agar tidak ada air yang menggenang, namun pada kenyataannya garis-garis tersebut dipenuhi sampah, daun-daun kering dan rumput liar.

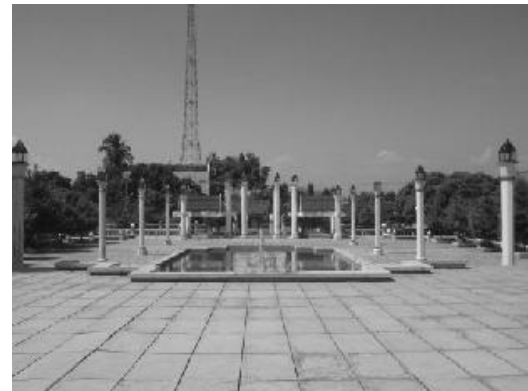

Gambar 14. Halaman masjid

(Sumber: Hasil dokumentasi, 2010)

- Masjid ini memiliki kolam yang luas pada bagian tengah halaman. Kolam memang identik dengan bangunan Islam, keberadaan kolam harus selalau terawat dan bersih yang mencerminkan kebersihan kesucian Islam, namun tidak demikian yang terjadi pada kolam masjid ini. Kolam masjid sangat luas namun kondisinya tidak terawat, keruh dan berlumut. Terdapat juga di dalamnya ikan-ikan yang cukup banyak sehingga kotoran ikan juga ikut membuat kolam menjadi keruh jika tidak sering dibersihkan.

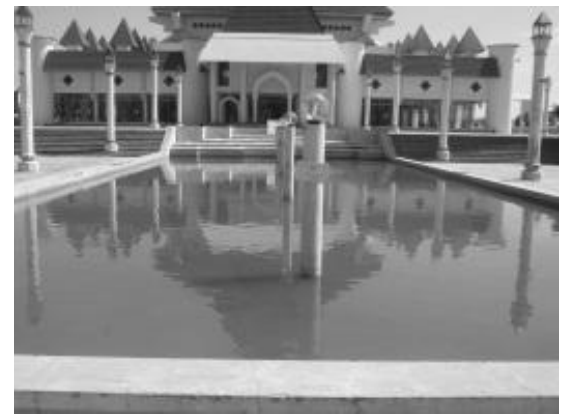

Gambar 15. Kolam masjid

(Sumber: Hasil dokumentasi, 2010)

- Pada tempat wudhu tidak ada tempat untuk mencuci kaki yang kotor, baik berupa kolam pencuci kaki maupun kran sebelum masuk area 
wudhu, sehingga lantai suci bisa saja menjadi najis walaupun terlihat bersih.

- Tempat wudhu dan masjid hanya dihubungkan dengan papan lantai beton setinggi $10 \mathrm{~cm}$ yang dilapisi karet. Posisi jalan ini juga melintang dengan jalur sirkulasi kotor sisi samping masjid. Dengan ketinggian dan letak tersebut menjadikan papan ini cepat kotor, apalagi jika basah bisa menjadi najis.

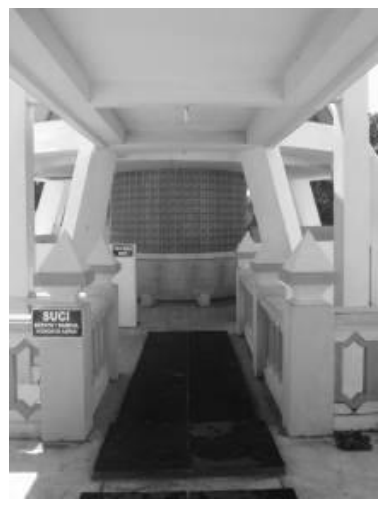

Gambar 16. Tempat wudhu

(Sumber: Hasil dokumentasi, 2010)

- Pada kamar mandi masjid terdapat kamar mandi/toilet dan ruang urinari untuk laki-laki. Ruang urinari sangat kotor dan rusak tidak terpakai.

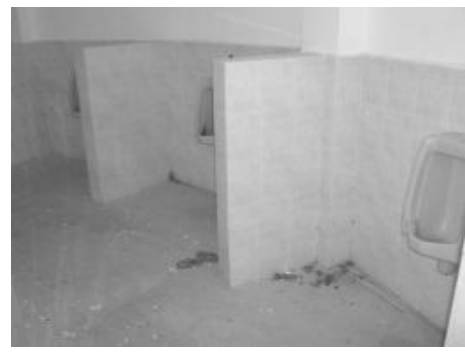

Gambar 17. Urinari

(Sumber: Hasil dokumentasi, 2010)

- Lantai kamar mandi/toilet tergenangi air luapan dari bak mandi sehingga lantai menjadi berlumut dan kotor.

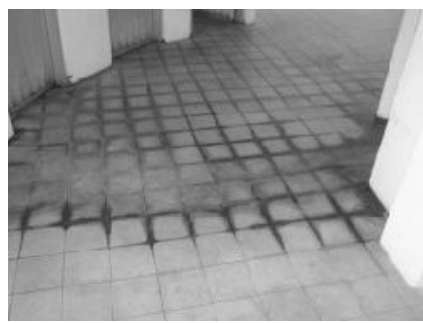

Gambar 18. Lantai toilet

(Sumber: Hasil dokumentasi, 2010)

- Tidak adanya kolam atau kran air untuk mencuci kaki antara area kamar mandi dan masjid.
Masjid AR. Fachruddin UMM

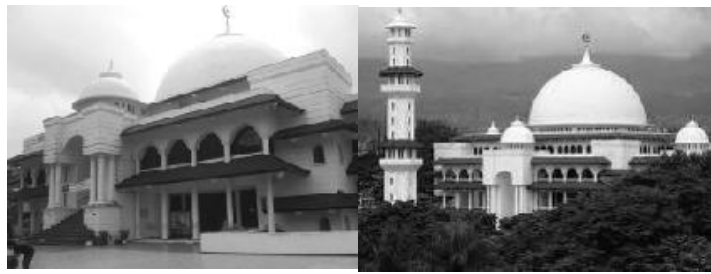

Gambar 19. Masjid AR. Fachruddin Universitas Muhammadiyah Malang (UMM)

(Sumber: Hasil dokumentasi, 2010)

Masjid AR. Fachruddin merupakan masjid kampus Universitas Muhammadiyah Malang. Masjid ini berdiri di atas tapak berkontur. Bangunan bagian bawah digunakan untuk administrasi kampus, sedangkan bagian atas digunakan untuk bangunan masjid. Pada sisi dalam, di samping area wudhu juga terdapat ruang-ruang perkuliahan. Begitu juga untuk lantai dua dan tiga masjid, terdapat ruang-ruang perkuliahan. Masjid ini juga tidak terlalu memiliki banyak ornamen pada dinding interior maupun eksteriornya.

Untuk aspek kebersihan dan kesucian dalam arsitektur masjid, masjid ini memiliki kelebihan sebagai berikut:

- Memiliki beda ketinggian level permukaan masjid dengan lingkungan sekitar segingga bangunan masjid tidak mudah kotor.

- Memiliki ruang kosong sebagai halaman yang memberi jarak antara jalan dengan bangunan utama. Ketinggian jalan raya juga lebih rendah dari ketinggian halaman masjid.

- Tempat wudhu dan kamar mandi berada pada sisi bawah bangunan masjid dan sebelum masuk area wudhu terdapat kolam pencuci kaki, sedangkan untuk pengunjung yang kakinya sudah suci bisa langsung masuk masjid atau jika ingin berwudhu terdapat tangga turun menuju tempat wudhu tanpa melalui kolam pencucian kaki.

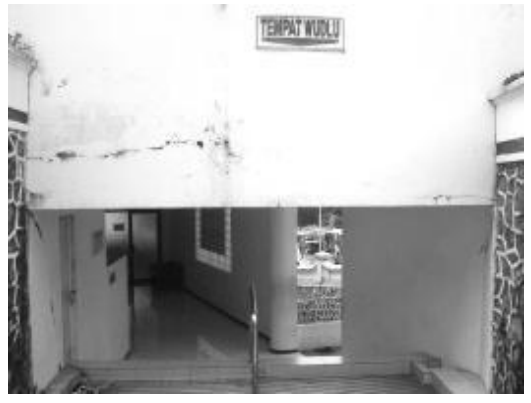

Gambar 20. Tempat wudhu

(Sumber: Hasil dokumentasi, 2010)

- Area kamar mandi/toilet sejajar dengan tempat wudhu yang memudahkan perawatan kebersihannya. 


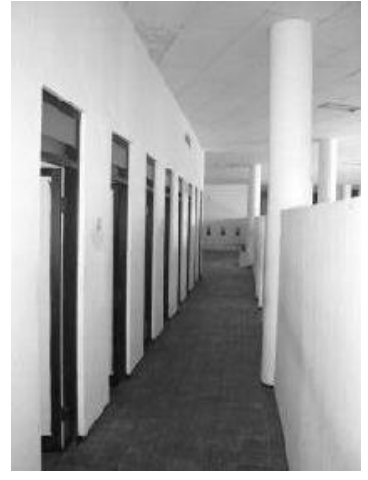

Gambar 21. Tempat wudhu dan toilet (Sumber: Hasil dokumentasi, 2010)

- Sistem sirkulasi cahaya dan udara yang cukup dengan komponen dinding, pintu, dan jendela yang dapat mencegah kelembaban pada interior bangunan.

Masjid ini juga memiliki kelemahan desain arsitekturnya terkait dengan aspek kebersihan dan kesucian, sebagai berikut:

- Terdapat pohon-pohon rindang besar pada sisi tepi halaman yang daun-daunnya berguguran mengotori halaman masjid. Pohon ini sebenarnya sangat bagus jika dirawat kebersihannya, dapat digunakan sebagai peneduh kawasan.

- Terdapat kran pada halaman yang terbuka yang sebenarnya digunakan untuk mencuci kaki, namun kenyataannya sering digunakan untuk berwudhu. Hal ini dikarenakan tidak sesuai dengan fungsinya menjadikan sekitar kran basah dan kotor.

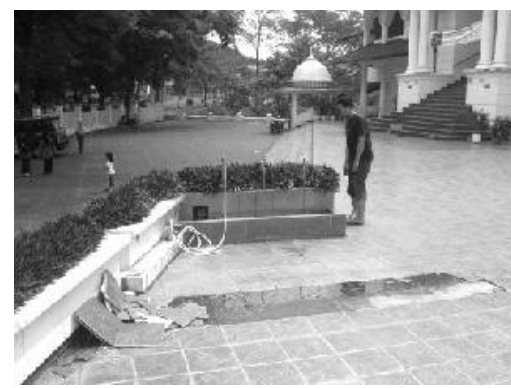

Gambar 22. Tempat mencuci kaki (Sumber: Hasil dokumentasi, 2010)

- Tidak terisinya air pada kolam tempat mencuci kaki kotor pada tempat wudhu. Hal ini mengakibatkan keberadaan kolam tempat mencuci kaki ini menjadi tidak efektif. Hal ini tentu saja sangat disayangkan, karena kesucian area wudhu menjadi tidak terjamin dari najis. Secara kasat mata terlihat bahwa area wudhu terkesan jorok akibat bercampurnya jejak kaki penggunanya di lantai yang becek.

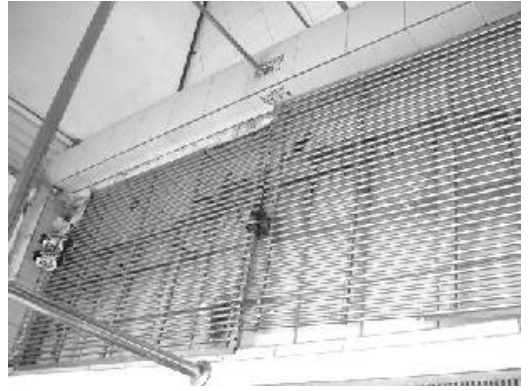

Gambar 23. Kolam pencuci kaki (Sumber: Hasil dokumentasi, 2010)

- Tidak terdapat pijakan kaki pada saat berwudhu membasuh kaki, sehingga dinding sebelah kran menjadi kotor dan berlumut.

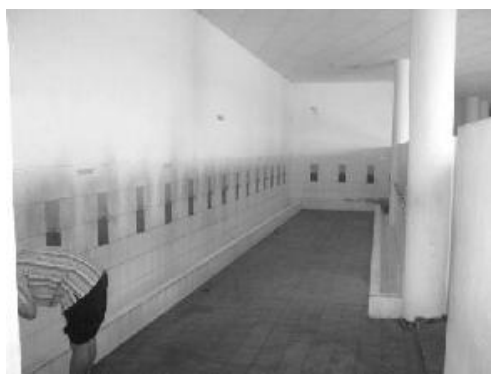

Gambar 24. Tempat wudhu

(Sumber: Hasil dokumentasi, 2010)

- Pada dinding eksterior bangunan masjid kotor karena tingginya dinding yang sulit dijangkau untuk perawatannya.

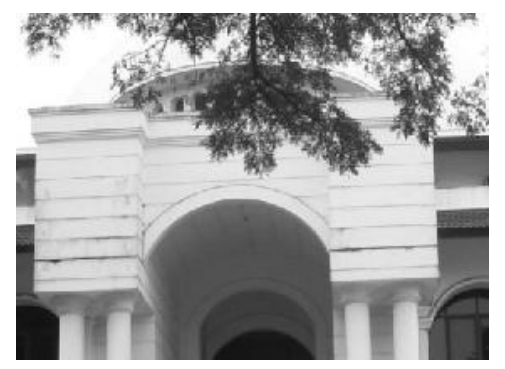

Gambar 25. Ornamen dinding eksterior yang kotor (Sumber: Hasil dokumentasi, 2010)

\section{Rekomendasi Desain}

Untuk menghasilkan rancangan masjid yang memperhatikan aspek kebersihan dan kesucian, berbagai permasalahan tersebut sebenarnya dapat dipecahkan, di antaranya dengan beberapa rekomendasi desain sebagai berikut:

\section{Perbedaan level permukaan lantai}

Level terendah adalah permukaan tanah atau lingkungan sekitar, kemudian level selanjutnya taman dan halaman. Untuk halaman bisa sejajar dengan taman maupun dapat juga lebih tinggi. Sementara itu, lantai masjid yang digunakan untuk 
shalat diletakkan di level teratas. Konsep ini merupakan konsep tata letak yang mengutamakan kebersihan dan kesucian, namun tetap harus diperhatikan ukuran ketinggian levelnya, yang pada intinya tetap memudahkan para pengunjung atau jama'ah, terutama anak kecil, orang tua, dan penyandang cacat.

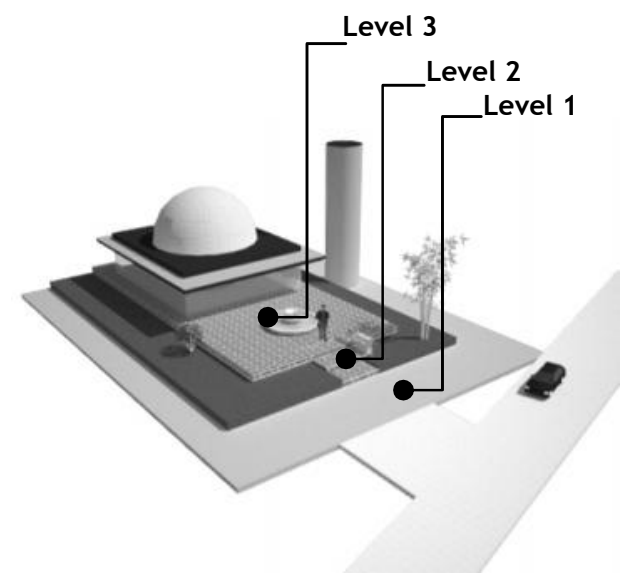

Gambar 26. Perbedaan level permukaan (Sumber: Hasil analisis, 2010)

\section{Jarak antara jalan raya dengan bangunan}

Perlu diperhatikan dan diterapkan terkait GSB, KLB dan KDB. Keberadaan jarak yang optimal antara bangunan masjid dengan jalan raya juga bermanfaat untuk mengurangi banyaknya debu yang masuk ke dalam ruang shalat. Selain itu, ketenangan ruang shalat juga lebih terjaga. Namun demikian, jarak yang terlalu jauh antara gerbang masuk dengan bangunan masjid dapat mengakibatkan kelelahan bagi para pejalan kaki, lanjut usia dan penyandang cacat. Karenanya, seorang arsitek perlu mempertimbangkan jarak yang optimal untuk meraih seluruh manfaat di atas tanpa menimbulkan mudharat di lain pihak.

\section{Fasilitas untuk Mencuci kaki}

a. Pencuci kaki luar

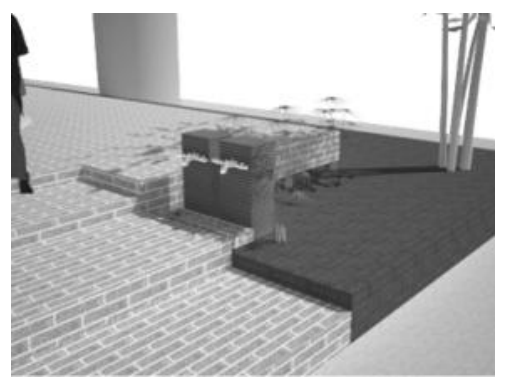

Gambar 27. Kran pencuci kaki sebelum masuk masjid (Sumber: Hasil analisis, 2010)

Tersedianya beberapa kran harus memiliki perletakan yang mudah diakses dan terlihat dari akses jalan ke dan dari masjid. Kran bisa digunakan untuk menggantikan kolam pencuci kaki antara ruang luar dengan masjid. Jika menggunakan kolam pencuci kaki, sebaiknya diletakkan dengan sedikit jarak dari lantai pertama masjid. Hal ini untuk menghindari basah yang berlebihan pada lantai masjid. Ukurannya harus cukup memadai dan dilengkapi dengan mekanisme yang memungkinkan air mengalir.

b. Pencuci kaki wudhu dan masjid

Kolam pencuci kaki sebaiknya juga dapat mengalir airnya sehingga terjadi pergantian air dan dilakukan perawatan rutin untuk menghindari kolam dari lumut dan karat(jika menggunakan besi sebagai alas kolam dan pegangan).

c. Pencuci kaki toilet dan masjid

Karena toilet merupakan tempat untuk buang air kecil dan besar, maka perlu disediakan kran pencuci kaki dengan penampungnya. Kran ini diletakkan dekat dengan toilet dan sedikit jauh dengan lantai masjid agar najis tidak menyebar kemana-mana.

Sirkulasi dan posisi tempat wudhu dan toilet dengan ruang shalat

Tempat wudhu dan toilet dapat diletakkan di sisi kanan dan kiri, laki-laki dan perempuan dipisah. Tidak terlalu jauh dengan masjid untuk memudahkan akses dan terjaga kesuciannya.

Untuk penghubung, lebih baik disediakan papan-papan suci yang memiliki ketinggian yang cukup dari permukaan lantai kotor, sehingga alas kaki sebelumnya sudah terlepas. Papan tersebut harus cepat kering dan tidak licin. Dileteakkan pada salah satu sisi khusus yang tidak melintasi jalan kotor.

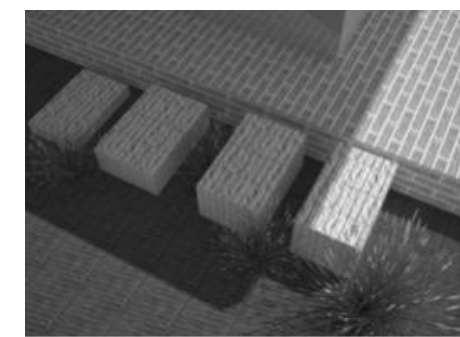

Gambar 28. Pemakaian papan berundak (Sumber: Hasil analisis, 2010)

\section{Perawatan ornamen}

Banyak ornamen masjid yang beraneka ragam, ornamen jika tidak dilakukan perawatan kebersihan yang baik akan sulit untuk dibersihkan. Desain arsitektur masjid lebih baik juga memikirkan bagaimana perwatan ornamen tersebut, misal dengan penyediaan elemen khusus sebagai estetik dan juga dapat digunakan untuk menjangkau 
perawatan kebersihan ornamen, penggunaan material yang mudah dibersihkan dan lain sebagainya.

\section{Sirkulasi cahaya dan udara}

Siklus cahaya dan udara harus diperhatikan untuk menghindari kotornya udara dan kelembapan ruang. Sirkulasi yang baik dapat dicapai dengan pemakaian material kaca pada dinding, jendela maupun pintu dan mengurangi elemen-elemen bangunan masif yang menghalangi siklus udara dan cahaya. Harus terjadi cross ventilation untuk siklus udara.

\section{Halaman masjid}

Untuk iklim tropis, sebaiknya menghindari halaman terbuka yang luas dengan lantai diplester atau dibangun, karena sangat panas dan kurang fungsional. Sedangkan halaman masjid biasanya hanya digunakan pada waktu-waktu tertentu saat jama'ah penuh atau terdapat kegiatan keagamaan, jadi tidak selalu dipakai. Desain halaman dapat dilakukan dengan beberapa cara berikut:

a. Penggunaan atap

Dapat menggunakan membran atau skylight yang tidak meneruskan panas, lebih bagus lagi jika didesain buka tutup secara otomatis.

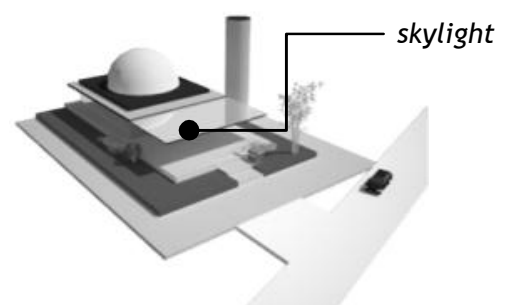

Gambar 29. Penggunaan atap untuk halaman (Sumber: hasil analisis, 2010)

\section{b. Terbuka}

Untuk halaman terbuka sebaiknya tidak terlalu luas dan pemilihan material lantai yang tidak menyerap panas berlebih dan bersih. Halaman lainnya bisa ditambahkan vegetasi peneduh yang mudah dijaga kebersihannya. Drainase lantai halaman sebaiknya memiliki kemiringan 5-10 ${ }^{\circ}$ untuk mengalirkan air dan memiliki alur air di tepi-tepinya.

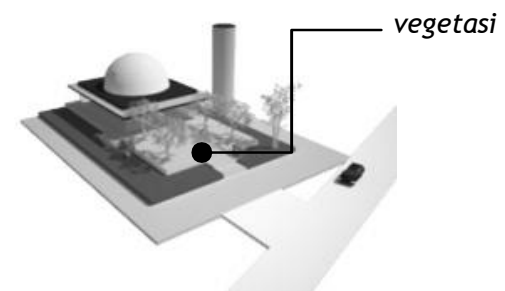

Gambar 30. Penggunaan vegetasi untuk halaman (Sumber: Hasil analisis, 2010)

\section{Kolam taman masjid}

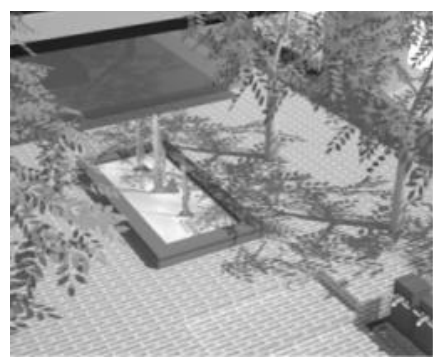

Gambar 31. Kolam masjid

(Sumber: Hasil analisis, 2010)

Kolam sebagai unsur estetik menjadi point of view dari taman masjid sehingga harus diperhatikan perwatan kebersihan dan keindahannya. Kolam harus diperhatikan dimensinya, perbandingan luas lahan dan kolam serta pertimbangan fungsinya, selain itu airnya juga harus mengalir, jika tidak mengalir bisa dilakukan siklus air setempat seperti sistem aquarium, terdapat penyaringan dan pemutaran air sehingga air tetap bersih dan bertahan cukup lama.

\section{Tempat wudhu dan kamar mandi}

a. Urinari (tempat kencing laki-laki) dan toilet

Percikan air kencing yang sangat lembut tetap dihukumi najis, sehingga kurang dianjurkan mendesain urinari. Apalagi jika ada orang yang tak terbiasa menggunakannya, pasti mengalami kesulitan untuk mensucikannya. Begitu juga untuk toilet duduk yang percikan airnya kadang mengenai badan dan pakain, Jadi lebih baik menggunakan toilet jongkok (sunah nabi untuk buang air kecil dan besar dengan jongkok)

b. Desain tempat wudhu

Desain tempat wudhu sangat beraneka ragam, namun dalam aspek kebersihan dan kesucian lebih baik didesain dengan menggunakan kran dengan penampung air yang must'mal dibawahnya dengan pembatasnya yang cukup agar air tidak memercik kemana-mana, terdapat pijakan untuk kaki pada saat mambasuh kaki sehingga tangan tidak perlu menopang dinding yang dapat membuat dinding kotor

\section{c. Lantai}

Memilih material lantai yang tidak licin dan mudah dibersihkan. Menyediakan alur air agar lantai cepat kering lebih bagus lagi jika lantai tersebut mendapat pencahayaan dari matahari.

\section{Vegetasi}

Vegetasi diperlukan untuk peneduh halaman maupun ornamen naturali bagi masjid. Hal yang perlu diperhatikan adalah pemilihan jenis dan karakteristik pohon, kemudian perawatan dan menjaga kebersihan lingkungan sekitarnya. 


\section{Referensi}

1 http://en.wikipedia.org/wiki/masjidtahun 2009 diakses pada 23 Mei 2010

2 http://en.wikipedia.org/wiki/masjidtahun 2009 diakses pada 23 Mei 2010

3 QS. at-Taubah [9]: 108

4 HR. Tirmidzi
$5 \quad$ QS. al-Baqarah [2]: 222

6 Drs. Sulchan Yasyin. 1995. Kamus Pintar Bahasa Indonesia. Surabaya: Amanah

7 Dr. Said Ali. 2007. Tata Cara Bersuci Nabi. Bandung: Irsyad Baitus Salam

8 http://www.indoskripsi.com/kebersihan menurut_Islam.htm tahun 2009 diakses pada 23 Mei 2010 